\title{
Mouse models to unravel the role of inhaled pollutants on allergic sensitization and airway inflammation
}

\author{
Tania Maes ${ }^{1 *}$, Sharen Provoost ${ }^{1}$, Ellen A Lanckacker ${ }^{1}$, Didier D Cataldo ${ }^{2,3}$, Jeroen AJ Vanoirbeek ${ }^{4}$, Benoit Nemery ${ }^{4}$, \\ Kurt G Tournoy', Guy F Joos ${ }^{1}$
}

\begin{abstract}
Air pollutant exposure has been linked to a rise in wheezing illnesses. Clinical data highlight that exposure to mainstream tobacco smoke (MS) and environmental tobacco smoke (ETS) as well as exposure to diesel exhaust particles (DEP) could promote allergic sensitization or aggravate symptoms of asthma, suggesting a role for these inhaled pollutants in the pathogenesis of asthma. Mouse models are a valuable tool to study the potential effects of these pollutants in the pathogenesis of asthma, with the opportunity to investigate their impact during processes leading to sensitization, acute inflammation and chronic disease. Mice allow us to perform mechanistic studies and to evaluate the importance of specific cell types in asthma pathogenesis. In this review, the major clinical effects of tobacco smoke and diesel exhaust exposure regarding to asthma development and progression are described. Clinical data are compared with findings from murine models of asthma and inhalable pollutant exposure. Moreover, the potential mechanisms by which both pollutants could aggravate asthma are discussed.
\end{abstract}

\section{Introduction}

Asthma is a chronic inflammatory disorder of the airways. The clinical hallmark of asthma is bronchial hyperresponsiveness with recurrent episodes of wheezing, breathlessness, chest tightness and cough. These episodes are associated with variable airflow obstruction that is at least partially reversible [1].

Asthma is a considerable public health concern, with an increasing prevalence and an estimate of 300 million asthmatics worldwide. Although the cause of asthma is unknown, there are several risk factors that influence the development of asthma. These can be divided into host factors and environmental risk factors [1]. The allelic distribution of genes pre-disposing to atopy or airway hyperresponsivess is a typical host factor which determines asthma development and phenotype. Typical environmental factors are allergens (indoor or outdoor allergens, such as these originating from domestic mites, furred animals, cockroach, fungi, molds, yeasts and

\footnotetext{
* Correspondence: tania.maes@ugent.be
'Laboratory for Translational Research in Obstructive Pulmonary Diseases,

* Correspondence: tania.maes@ugent.be
'Laboratory for Translational Research in Obstructive Pulmonary Diseases,

Department of Respiratory Medicine, Ghent University Hospital, De Pintelaan 185, 9000 Ghent, Belgium
}

pollen), infections (mainly viruses), occupational sensitizers, tobacco smoke (both active and passive smoking) and indoor or outdoor pollution by gasses and particulate matter (PM) [1,2].

In their efforts to unravel the pathogenesis of asthma, researchers have mainly focussed on the basic immunologic mechanisms resulting in unwanted or exaggerated inflammation. Many uncertainties remain concerning why and how asthma develops during lifetime. The emerging hypothesis is that a failure of endogenous immune regulated tolerance mechanisms might be involved [3]. Alternatively, exposure to a more or less specific cocktail of allergens or pollutants might also lead to the development of an asthmatic phenotype [2]. Regardless of the mechanism, exposure of the airways to foreign agents (allergens or chemical agents) often represents the very first cause for an immune derailment. In later stages, sensitized individuals will be more susceptible to develop airway inflammation and symptoms. These processes can be present for a limited time or become chronic. In that view, the pathogenesis of allergic asthma comprises 3 phases: sensitization, acute inflammation and chronic disease. 
The association between exposure to inhalable pollutants such as cigarette smoke and PM (e.g. diesel exhaust) and respiratory morbidity has been recognized for a long time. The epidemiological association of increased exposure to air pollutants and the rise in frequency of wheezing illnesses led to the assumption that these pollutants are actively involved in the pathogenesis of asthma. While there is no doubt that inhaled pollutants can exacerbate the symptoms of asthma, it is also considerable (though less well established) that they play a role in inducing asthma or at least in driving incipient asthma into clinically obvious manifestations of the disease.

A widely used tool to evaluate the effects of inhaled pollutants on the development and aggravation of asthma consists in epidemiological studies. Controlled exposure studies in humans are informative as well, but are limited by practical and ethical issues. The use of animal models leads to more insights regarding the role of inhalable pollutants during sensitization and inflammation in asthma, with a unique opportunity to unravel the effects on the different phases of the development of the asthma pathology (Figure 1). The mouse has emerged as the animal of choice for modeling this disease [4]. In this review, we give a summary of the studies investigating the impact of inhaled pollutants on the onset, development or aggravation of asthma. We particularly focussed on tobacco smoke and PM, more specifically diesel exhaust particles (DEP).

\section{Health effects of tobacco smoke and diesel exhaust particles}

The World Health Organization (WHO) reports 1.15 billion smokers, of whom 200 million live in Europe [5]. The yearly production of cigarettes still increases in order to meet the people's wishes. Tobacco smoke is a complex mixture of more than 4000 components [6-8]. Researchers distinguish two different emissions from cigarettes. Mainstream smoke (MS) is the smoke actually inhaled by the cigarette smoker (active smoking), whereas side stream smoke is released from the burning end of the cigarette. In many epidemiologic studies, the

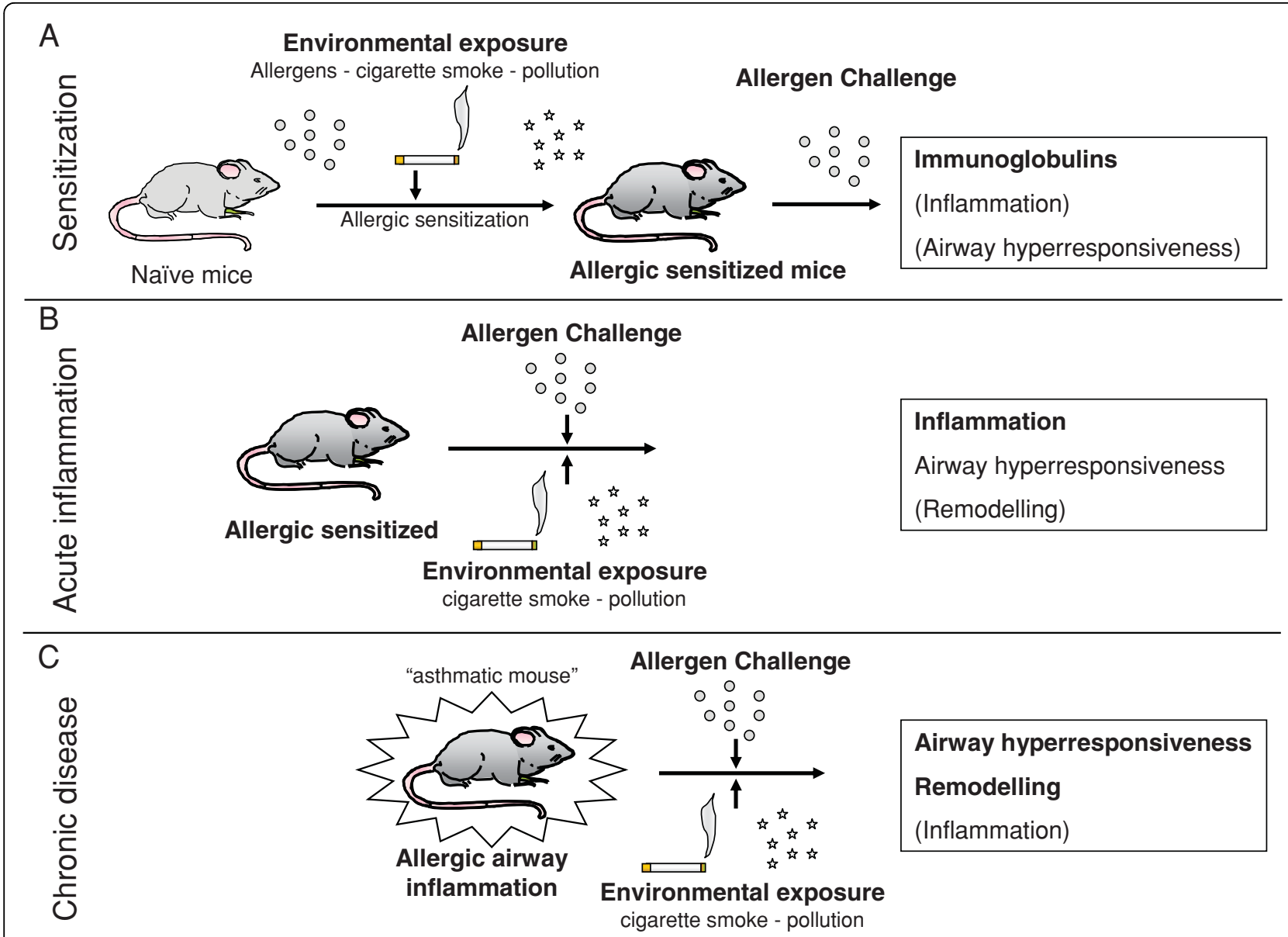

Figure 1 Schematic presentation of how the effects of environmental exposures, (aero)immunization and airway challenge on the 3 different phases of the asthma pathology (sensitization, acute inflammation and chronic disease) can be dissected in mice. 
term environmental tobacco smoke (ETS) is used, which is a mixture of sidestream smoke and exhaled mainstream smoke in the environment after dilution and aging. This mixed smoke is inhaled during passive smoking (also referred to as "second hand smoke"). Active and passive smoking contribute to the development of various respiratory health problems such as asthma and reduced lung function. In susceptible individuals, active smoking is associated with structural changes in the airways (remodelling, especially of the small airways) and results in destruction of the lung parenchyma (emphysema) $[9,10]$. Chronic exposure to cigarette smoke induces clinically significant chronic obstructive pulmonary disease (COPD) in 20\% of the smokers. Besides COPD, tobacco smoking also causes lung cancer and other adverse health effects [5].

The WHO reports that there is consistent evidence that airborne particulate matter (PM) has a measurable public health impact [11]. The range of health effects is broad, but affects predominantly respiratory and cardiovascular systems. All population is affected, albeit susceptibility to the pollution may vary with age or health status. The risk for various outcomes increases with exposure and adverse effects of PM were demonstrated after both short-term and long-term exposure [11]. Diesel exhaust particles (DEP) are an important component in ambient air pollution and respirable particulate matter. They consist of a carbon core and adsorbed organic substances such as polycyclic aromatic hydrocarbons, and contain small amounts of sulphate, nitrate, metals and other trace elements $[12,13]$. The majority of diesel exhaust particles are ultrafine particles with a diameter around $0.1 \mu \mathrm{m}$, that are highly respirable, reaching the alveoli and the systemic circulation [14]. DEP exposure can induce acute irritation to eyes and throat, lightheadedness and nausea, and has been associated with increased respiratory symptoms (cough, phlegm, chronic bronchitis, asthma), increased lung cancer risk and increased risk for total mortality and cardiopulmonary mortality [13-15].

\section{Clinical data on the effect of inhaled pollutants on allergic sensitization and asthma}

It is generally accepted that sensitization to allergens is a crucial risk factor for the development of asthma. Studying the potential effects of environmental factors on allergic sensitization is thus relevant. Although the nature of the inhaled particles from cigarette smoke and DEP differs, they induce a similar inflammatory response which is characterized by neutrophils, T-lymphocytes, increased levels of IL-8 and IL-6, along with a decreased phagocytic capacity of alveolar macrophages [12,14,16-19]. One can hypothesize that both cigarette smoke and DEP deploy similar mechanisms, creating an environment which facilitates allergic sensitization and asthma development.

Epidemiological studies cannot provide the proof that cigarette smoke or DEP exposure are causative factors in the development of asthma. However, associations between the risk of developing asthma and inhalable pollutant exposure provide strong indications that there might be a causal relationship. Many data support the hypothesis that ETS exposure (passive smoking) contributes to the development of both childhood asthma and adult onset asthma [20]. In utero exposure to maternal smoking or any smoking at home significantly increases the risk for developing childhood asthma [21,22]. The prevalence of asthma, wheezing, chronic cough and breathlessness in children increases with the number of parents smoking, suggesting a dose-response [23]. ETS exposure during childhood [24] or in adults - mainly occupational exposure - is also associated with the development of adult asthma and other respiratory symptoms [25] in a dose-dependent manner [26]. However, the relationship between ETS exposure and allergic sensitization (as evaluated by serum IgE and skin prick tests) is less evident $[27,28]$. ETS can promote the induction of Th2 cytokines in nasal fluid of allergic patients, indicative of allergic response exacerbation by ETS in human beings [29]. Passive smoking is indeed dose-dependently related to greater asthma severity, diminished pulmonary function and poorer asthma control in adults $[30,31]$ as well as children [32,33]. The correlation between ETS and asthma prevalence and severity is extensively reviewed in [34].

Contrasting with ETS, the impact of active smoking on the development of asthma is more controversial. Some reports state that active smoking is not a risk factor for adult onset asthma [35], whereas other reports demonstrate the opposite [36,37]. Active smoking during adolescence increases the risk of new onset asthma $[38,39]$. Asthma prevalence is also higher both in adolescents [40] and among the elderly [41] who smoke. Current wheezing, current asthma and lifetime asthma are all related to active smoking [42]. As for passive smoking, the relationship between active smoking and atopy is again controversial $[43,44]$. Active smoking is associated with asthma severity, with higher asthma severity scores [35] and less controlled asthma [45]. Smoking asthmatics have a reduced lung function [46], greater decline in FEV1 with age [47] and the lung function is inversely correlated with the amount of cigarettes smoked per day [48]. Active smoking in asthmatics also impairs the therapeutic response to corticosteroids [49].

Many epidemiological data suggest that traffic related air pollution (rather than DEP as such) is a risk factor for wheezing, asthma prevalence and allergic 
sensitization (reviewed in [50-52]), however the evidence is not so strong. Nevertheless, several recent birth cohorts demonstrated positive correlations between exposure to traffic pollution and atopic diseases and allergic sensitization in children $[53,54]$. In contrast to the epidemiological knowledge, experimental approaches have convincingly demonstrated that DEP can facilitate the induction of allergic sensitization. Besides their ability to increase in vivo IgE and cytokine production at the upper respiratory mucosa, DEP can facilitate sensitization to a neoallergen, with the production of allergenspecific IgE and skewing of cytokine production to a Thelper cell 2 pattern $[15,55,56]$. Ambient air pollution is associated with asthma severity $[34,57,58]$, but reported effects of DEP on aggravation of asthma in controlled exposure studies differ, possibly due to the variety of exposure regimens used in experimental protocols $[17,59]$. A recent crossover study in London in mild to moderate asthmatics with real life exposure to diesel traffic demonstrated an asymptomatic, though significant reduction in lung function $\left(\mathrm{FEV}_{1}\right.$ and $\left.\mathrm{FVC}\right)$, most pronounced in the moderate asthmatics and accompanied by increases in inflammatory markers [60].

\section{Inhaled pollutants and murine allergic sensitization}

Mouse models of asthma allow analyses in precisely defined environmental conditions. A commonly used experimental allergen in mouse models is the inert protein ovalbumin (OVA), but also house dust mite, pollen and Aspergillus models exist. Sensitization towards OVA, either naturally or upon inhalational exposure, does generally not occur in mice. On the contrary, mice develop inhalational tolerance and become refractory to subsequent immunization attempts by OVA intraperitoneally [61,62]. Some studies intend to break inhalational tolerance by combined exposure regimens in the absence of any intraperitoneal injection, whereas other studies examine the aggravating or modulating effects of inhaled pollutants on the sensitization phase in previously sensitized animals (Figure 1). The impact of tobacco smoke or DEP on allergic sensitization or inflammation in different mouse asthma models will be discussed. In cigarette smoke exposure models, both nose-only and whole body exposures are performed. Side stream smoke is often used as a surrogate for ETS and will be referred to as ETS hereafter. DE(P) models use intranasal or intratracheal DEP-applications or diesel exhaust (DE) inhalation. Additional files 1, 2 and 3 give a detailed overview of methodologies and results from studies with ETS, MS and DEP respectively.

\section{Cigarette smoking and sensitization in mice (Additional files 1 and 2)}

Rumold and colleagues proved that ETS (passive smoking) can act as an adjuvant for allergic sensitization to OVA [63] (Additional file 1). The co-exposure to ETS and aerosolized OVA induced de novo sensitization, with the development of a memory response [63]. ETS also enhanced allergic sensitization towards intraperitoneal OVA and the effects of ETS were more profound in females, compared to male mice $[64,65]$. However, in other reports the effects were less clear [66,67]. For example, chronic postnatal exposure to combination of OVA and ETS tended to reduce OVA-specific immunoglobulin production compared to OVA-alone exposure and showed no evident effects on pulmonary inflammation, although airway hyperresponsiveness was increased. Accordingly, ETS-exposure prior to and concomitant with OVA-aerosol exposure could not overcome airway tolerance in three different mouse strains with a different level of susceptibility to airway hyperresponsiveness $(\mathrm{A} / \mathrm{J}$, $\mathrm{BALB} / \mathrm{c}$ and C57BL/6) [67]. Also in utero exposure to ETS did not affect antibody production or airway inflammation towards postnatal aerosolized OVA in unsensitized animals, although it did increase airway hyperresponsiveness [68]. ETS exposure prior to, during and after several intranasal sensitizations towards another allergen, Aspergillus fumigatus (Af), did not affect IgEproduction, but it did increase blood eosinophilia and airway hyperresponsiveness [69]. Thus, despite the absence of IgE markers of sensitization, ETS repeatedly aggravated hyperresponsiveness in different models.

Not all reports are univocal, but some murine models support the hypothesis that ETS can behave as an adjuvant and facilitate allergic sensitization. Although not yet proven, facilitation of allergic sensitization could explain the reported associations between ETS and the increased risk for developing asthma in humans.

In a model mimicking active smoking, in which mice were first exposed for 2-3 months to mainstream cigarette smoke (MS) and subsequently sensitized to OVA or ragweed via the mucosa, smoke exposure increased Th2-cytokine production by splenocytes (suggestive for a heightened allergic sensitization), but attenuated pulmonary inflammation and airway hyperresponsiveness [70] (Additional file 2). In another model without intraperitoneal sensitization, MS could disrupt the normal tolerogenic immune response towards OVA [71]. While OVA aerosol could not induce per se any allergic inflammation, simultaneous exposure to OVA and MS induced OVA-specific IgE and IgG $_{1}$, pulmonary inflammation and goblet cell hyperplasia $[71,72]$. In a similar experimental setting, concurrent exposure to MS and OVA induced allergic sensitization with antigen-specific 
memory in a GM-CSF dependent fashion [73]. However, prolonged cigarette smoke exposure suppressed eosinophilic inflammation in this model, indicating that cigarette smoke potentially bears both adjuvant and antiinflammatory properties.

All reports with MS suggest that active smoking can facilitate sensitization in mice, however the data on the subsequent development of allergic inflammation in mice are contradictory. This underscores the need to further elucidate the impact of experimental conditions, which can favour inflammation or, on the contrary, suppress immunity, probably depending on the dose, method and duration of cigarette smoke exposure. Considering that the impact of active smoking on the development of asthma is controversial, these mouse models are very challenging and merit further investigation.

\section{Diesel exhaust particle exposure and sensitization in mice (Additional file 3)}

Muranaka and coworkers were the first to show that DEP can increase specific IgE towards OVA or Japanese Cedar Pollen (JCP) after intraperitoneal sensitization [74,75] (Additional file 3). Since then, many authors have described the adjuvant effects of DEP, using different immunization routes. DEP or diesel exhaust can increase OVA-specific IgE, and can increase IL-4 production and cell proliferation in mediastinal and cervical lymph nodes or spleen after intratracheal, intranasal and inhalational sensitization, respectively [76-78]. DEP can thus affect the antigen-specific IgE antibody responses through local and systemic T-cell activation. Similar observations were reported upon sensitization through injection into the footpad [79]. Both the organic matter adsorbed to DEP and the non-extractable carbon core are thought to be responsible for the adjuvant effect [79-81]. Several sensitization models using OVA or house dust mite (Der $f$ ) in presence of DEP revealed also increased antigen-specific IgG1 and IgG2 levels, besides increased antigen-specific IgE [81-88]. Moreover, DEP aggravates the observed pulmonary inflammation and goblet cell proliferation in these models.

In line with the experimental data in humans, DE or DEP (self-produced or commercially available reference material) have consistently shown to facilitate allergic sensitization. In contrast to the above mentioned effects of tobacco smoke, biological effects of DEP in mice seem to be less affected by experimental conditions.

\section{Inhaled pollutants and allergen-induced murine asthma models}

Different approaches can be used to evaluate the effects of inhaled pollutants on the pathogenesis of allergeninduced airway inflammation.
Firstly, experimental models can evaluate the effect on asthma development. Animals are challenged with allergen in the presence of inhalable pollutants and develop a typical asthmatic phenotype (IgE, pulmonary inflammation, T-cell responses, airway hyperresponsiveness, goblet cell hyperplasia and remodelling) (Figure 1B). The timepoint where the inhalable pollutant is introduced can vary: (1) before the first allergen challenge: assuming that an alteration of the pulmonary environment might induce a higher sensitivity to subsequent allergen challenge; (2) simultaneous exposure: assuming that the presence of the inhalable pollutant and the allergen can affect the pulmonary response to both agents, and in which a possible interaction between both agents can become relevant.

Secondly, models can also evaluate the aggravating effects of inhalable pollutants on mice with previously established allergic airway inflammation, reflecting the human situation of pollutant exposure in existing asthma (Figure 1C).

Additional files 4, 5 and 6 give a detailed overview of methodologies and reported observations in mouse models in which the effects of ETS, MS or DEP exposure on the development or aggravation of asthma were examined.

\section{Cigarette smoking and development or aggravation of} asthma in mouse models (Additional files 4 and 5)

Different in vivo studies have demonstrated that ETS can aggravate the allergic response in mice which were primed with OVA and had already mounted a Th2 response. Indeed, ETS exposure prior to and during allergen challenge in sensitized mice induces an upregulation of the allergic response, with increased systemic and pulmonary inflammation, which is more pronounced in females compared to males [64,65] (Figure 1B) (Additional file 4). In this experimental setup, the mice, however, also exhibited heightened allergic sensitization (see section on ETS and sensitization), hampering the distinction between effects on sensitization, on asthma development or on both. Enhanced pulmonary inflammation, remodelling and hyperresponsiveness were also observed upon chronic co-exposure to ETS and OVA in "asthmatic mice" (Figure 1C) [89]. In utero exposure to ETS has long term effects on the development of allergic inflammation and exacerbates subsequent adult responses to initial allergen exposure [68]. Maternal smoking during pregnancy also induces airway remodelling in mice offspring [90].

In contrast to the reports on ETS, the effects of mainstream cigarette smoke (MS) on the development and exacerbation of allergic inflammation in mice are a matter of debate [91-93] (Additional file 5). Some authors 
reported that MS exposure inhibits OVA-induced airway hyperresponsiveness and reduces inflammation in a model of established asthma [70,92]. However, in a $\mathrm{BALB} / \mathrm{c}$ model examining the development of allergic inflammation, Moerloose et al [93] demonstrated that acute concurrent exposure to allergen (OVA) and MS enhances the allergic pulmonary inflammation, and augments OVA-specific IgE production and airway hyperresponsiveness [93]. These acute effects were confirmed in C57/Bl6 mice [94]. Upon prolonged exposures, however, the combination OVA/smoke could delay - though not prevent - the development of tolerance, which is classically observed upon chronic OVA-aerosol exposures [94]. In an "asthmatic mouse", chronic co-exposure to MS and OVA did neither aggravate airway inflammation, OVA-specific IgE production and remodelling, nor accelerate emphysema development [95]. Interestingly, smoke exposure did increase OVA-specific IgE levels in sensitized mice, suggesting that atopic smokers may be at risk for increased allergen-specific IgE, thus increasing their risk for developing asthma [95]. Recently, the importance of the smoke exposure regimens was highlighted, since high dose, but not low dose MS suppressed allergic airway inflammation by inhibiting T-cell function [96].

\section{Complexity of cigarette smoke exposure models}

Although is generally accepted that both active and passive smoking aggravate the severity of asthma in man, murine models suggest the relationship is not that simple. In murine asthma models, there is a discrepancy in the effects of ETS and MS. ETS consistently aggravated all measured outcomes in murine models, similar to observations in humans. MS however, aggravated the development of allergic asthma on the one hand, but it could also suppress established allergic inflammation on the other hand. The origin of the discrepancy between ETS and MS is difficult to define, but can relate to differences in the dose, chemical composition or even particle size of ETS vs MS. Mimicking active smoking in mice is a challenging task and is possibly more subject to variation than ETS exposure. Since mice not "just light a cigarette and smoke", they receive MS by whole body exposure or nose-only exposure. Besides the dose, carbon monoxide levels and stress by the experimental environment (exposure in group vs. individual restrainers) could conceivably impact the immunological response. High doses of cigarette smoke could suppress $\mathrm{T}$-cell or dendritic cell function or induce an increase of blood carboxyhemoglobin levels, which may have immunosuppressive effects on the ensuing allergic inflammation $[96,97]$, whereas low doses of cigarette smoke might promote allergic inflammation. The complexity of effects induced by tobacco smoke exposure is due to its multipartite nature. Immunosuppressive and antiinflammatory effects of tobacco smoke are mediated by its oxidants, by carbon monoxide, nicotine and some aromatic compounds that modify transcriptional programmes [98]. Cigarette smoke can moreover chemically modify signalling pathways and extracellular matrix through acetylation, nitrosylation, carbonylation and oxidation which affects cell survival, activation and differentiation [98]. On one hand, smoke exposure can lead to chronic inflammation and damaged respiratory epithelium. On the other hand, tobacco smoking can also acutely suppress epithelial function by increasing permeability and impairing mucociliary clearance. Cigarette smoke can induce infiltration of alveolae by activated macrophages, producing pro-inflammatory mediators, reactive oxygen species and proteolytic enzymes, resulting in inflammation and tissue damage. But, it can also compromise macrophage phagocytic capacity or skew their inflammatory mediator profile [98]. This dual nature of smoke acting on biological processes as both stimulus and suppressor is probably differently reflected in each experimental system, adding to the discrepancies in the reported observations.

In addition, in chronic models with MS or ETS exposure, there is a possibility to obtain phenotypes which overlap with COPD [99-101]. The development of emphysema and airway remodeling for example, which have been reported upon chronic MS exposure $[99,100,102]$ could affect the pulmonary function measurements in an allergic setting. Also lymphoid follicle formation which has been reported in COPD mouse models [103] could contribute to allergic sensitization. This COPD aspect adds to the complexity in interpreting the data, but it can also lead to the development of clinically relevant models of an asthma/COPD overlap syndrome. In any case, further analysis of the animal models and elucidation of the involved mechanisms could provide us with valuable tools to further unravel how tobacco smoke aggravates allergic asthma in humans.

\section{DEP and development or aggravation of asthma in mouse models (Additional file 6)}

Besides their effects on allergic sensitization, diesel exhaust particles can enhance the allergen-induced airway inflammation. In most studies, animals are exposed to DEP or diesel exhaust throughout both periods of sensitization and allergen challenge, which renders it difficult to dissect effects on either sensitization or developing airway inflammation. Most reports, however, show that both intratracheal instillation of DEP and inhalation of diesel exhaust increase the allergic response towards OVA or house dust mite in a dosedependent way with enhanced pulmonary infiltration 
and local cytokine production, increased goblet cell hyperplasia, increased airway hyperresponsiveness and, in some strains, increased levels of allergen-specific immunoglobulins [104-112] (Additional file 6).

The aggravating effect of DEP on pre-existent asthma has been examined by exposing previously sensitized and allergen-challenged "asthmatic" mice to $\mathrm{DE}(\mathrm{P})$ without further exposure to allergen. In two different models, DE and DEP-exposure clearly increased airway hyperresponsiveness [113,114], but the effects rapidly subsided with continued DE-exposure [113]. The impact on pulmonary inflammation was, however, less pronounced, with no effects of $\mathrm{DE}(\mathrm{P})$ on BAL cell numbers and limited effects in the lung.

The above mentioned reports demonstrate that DEP facilitate allergic inflammation and aggravate airway hyperresponsiveness in murine models and correspond with epidemiological data associating particulate air pollution with asthma severity.

\section{Effects of inhaled pollutants in other animal asthma models}

In guinea pigs, research focussed mainly on the effects of smoke on airway hyperresponsiveness. Allergen-sensitized animals show an augmented bronchomotor response towards acute MS inhalation compared to non-sensitized animals, which is mediated by endogeneous tachykinins [115]. These neuropeptides affect airway smooth muscle tone, vascular permeability, mucus secretion and the release of inflammatory mediators, leading to neurogenic inflammation. Chronic MS exposure significantly increased airway hyperresponsiveness upon allergen challenge in sensitized animals, and upon capsaicin challenge independent of sensitization, indicating that MS can act as an adjuvant for both antigenic and neurogenic airway responsiveness [116].

The effects of DEP on sensitization and the development of allergic airway inflammation were evaluated in Brown Norway rats, using timothy grass pollen, house dust mite or OVA as allergen. As for mice, DEP exposure generally increased the levels of allergen-specific IgE and IgG [117-121]. Also increased eosinophilic airway inflammation $[118,119,122]$ and hyperresponsiveness [118] could be demonstrated, albeit not in all models $[117,120,121]$.

\section{Mechanistic view on the clinical impact of inhaled pollutants on asthma}

The proposed mechanisms by which DEP and cigarette smoke favour the allergic sensitization, development and aggravation of asthma have been reviewed previously and are based on reports in mice and man [12,123,124]. Table 1 gives an overview of similarities and differences in mechanistic observations for DEP and cigarette smoke in both species. The effects of both inhalable pollutants show striking analogies (Figure 2). Inducing damage of the airway epithelium is probably the primary event for both DEP and cigarette smoke. This occurs through direct toxicity or oxidative stress, hereby inducing inflammatory cell recruitment and inflammatory mediator release. Reactive oxygen species (ROS), released directly or indirectly by mononuclear phagocytes, can contribute to airway inflammation through the induction of cytokines, chemokines and adhesion molecules via the NF- $\kappa$ B pathway and mitogen-activated protein kinase cascades in macrophages and epithelial cells. This inflamed pulmonary environment has the ability to attract dendritic cells and enhance their activation, thereby increasing allergen capture and transport to the lymph nodes [72,125]. Moreover, tobacco smoke and DEP induce epithelial release of the growth factors GM-CSF and thymic stromal lymphopoietin (TSLP), which can stimulate dendritic cell activation [126-129]. Oxidative stress can by itself also affect epithelial cell surface integrity. Co-administration of allergen and inhalable pollutant could thus facilitate penetration of allergen into the epithelial layer, resulting in a more efficient uptake and subsequent antigen presentation by dendritic cells. DEP can adsorb allergens onto their surface and act as carriers to increase allergen deposition into the respiratory tract [130]. This, as well as the decreased phagocytic capacity of alveolar macrophages, could prolong allergen exposure and increase immune reactivity.

Besides the effects on the innate immune response, DEP or cigarette smoke can affect the adaptive responses towards allergens by enhancing costimulatory molecule expression and T-cell proliferation in the draining lymph nodes $[71,72,125,131]$. This results in an increased expression of Th2 cytokines, such as IL-4, IL-5 and IL13. Besides IL-5, also GM-CSF, and eotaxin are increased upon exposure to both inhalable pollutants and allergen. These mediators affect the eosinophil, one of the most prominent cells in the inflammation of allergic asthma, and are responsible for its maturation, survival and attraction to sites of inflammation. IL-4, IL-5 and IL-13 contribute to goblet cell hyperplasia, airway wall remodelling and airway hyperresponsiveness [129]. IgE and IgG production by B-cells is elevated by DEP and cigarette smoke through the action of IL-4. Binding of IgE, crosslinked with allergen, induces eosinophil and mast cell degranulation. The subsequent release of major basic protein and oxygen radicals induces bronchial inflammation, whereas histamine and leukotrienes induce airway hyperresponsiveness, thus further enhancing the effects of both inhaled pollutants on the asthmatic response.

In addition to the above mentioned and established mechanisms, there are newly emerging hypotheses by 
Table 1 Mechanistic effects of tobacco smoke and diesel exhaust in human and mouse

\begin{tabular}{|c|c|c|c|c|}
\hline \multicolumn{2}{|c|}{ TOBACCO SMOKE } & \multirow[b]{2}{*}{ BASAL EFFECTS } & \multicolumn{2}{|c|}{ DIESEL EXHAUST PARTICLES } \\
\hline Human & Mouse & & Human & Mouse \\
\hline$\widehat{\uparrow[100,144,145]}$ & $\uparrow[100,146]$ & $\begin{array}{l}\text { Oxidative Stress/Cell } \\
\text { damage }\end{array}$ & $\uparrow^{*}[15,147,148]$ & $\uparrow[15,86,149-151]$ \\
\hline$\uparrow[18,152]$ & $\uparrow[100,134,146,153,154], f[155]$ & TNF $\alpha$ & $\sim[156,157]$ & $\uparrow[106,158-161], \downarrow[107]$ \\
\hline$\widehat{\uparrow[18,152]}$ & $\uparrow[100,162,163], f[162]$ & $\mathrm{IL}-1 \beta$ & $\uparrow^{*}[148], \sim[156]$ & $\uparrow[135,150,161], \downarrow[159]$ \\
\hline$\uparrow[18,152]$ & $\uparrow[95,163], \sim[153]$ & IL-6 & $\uparrow[157,164], \sim[165]$ & $\uparrow[158,160], f[161]$ \\
\hline$\overline{\uparrow[18,152]}$ & $\uparrow[95,100,153,154,163]$ & $\mathrm{IL}-8 / \mathrm{KC}$ & $\begin{array}{l}\uparrow_{[17,156,166], \uparrow^{*}} \\
{[148,167-170], \sim[165]}\end{array}$ & $\uparrow[125,135,160]$ \\
\hline$\uparrow[18,152]$ & $\uparrow[95,100,134,153,154]$ & MCP-1 & $\uparrow^{*}[170]$ & $\uparrow[125,150,160], \sim[111]$ \\
\hline$\overline{\uparrow, \sim[171]}$ & $\uparrow[95], f[171]$ & GM-CSF & $\begin{array}{l}\uparrow^{*}[148,167-169], \sim \\
{[156,165], f^{*}[128]}\end{array}$ & $\uparrow[172], f[172], \downarrow[106], \sim[104]$ \\
\hline$\sim \sim 173]$ & $\sim[89]$ & Eotaxin & $\uparrow^{*}[174], \sim[175]$ & $\uparrow[112], \sim[111]$ \\
\hline$\uparrow[176]$ & $\uparrow[126]$ & TSLP & $\uparrow^{*}[127], f^{*}[127]$ & $\cdot$ \\
\hline$\uparrow[177-179]$ & $\uparrow[134,154,180], \downarrow[181]$ & Dendritic cell number & $\cdot$ & $\uparrow[125]$ \\
\hline$\cdot$ & $\uparrow[72], \sim[181]$ & DC transport of antigen & $\cdot$ & $\uparrow[125]$ \\
\hline$\uparrow[177,182]$ & $\uparrow[72,134,180], \downarrow[181]$ & $\begin{array}{l}\text { Costimulatory molecule } \\
\text { expression }\end{array}$ & $\uparrow^{*}[127,128]$ & $\uparrow[84,125]$ \\
\hline$\overline{\sim o r} \uparrow[183,184]$ & $\cdot$ & $\begin{array}{l}\text { Eosinophil number or } \\
\text { degranulation }\end{array}$ & $\uparrow^{*}[185], \sim[175,186]$, & $\uparrow \uparrow[109], \sim[106,107,110]$ \\
\hline$\overline{\uparrow[16,18,101,187]}$ & $\uparrow[134,153,154,180]$ & Neutrophil number & $\uparrow[15,17,157,175,186,188]$ & $\uparrow[86,104,106,107,110,112,125,158,159]$ \\
\hline$\overline{\uparrow[16,101]}$ & $\uparrow[134,153,154,180]$ & T or B-cell number & $\uparrow \uparrow[15,17,157,175,188], \sim[186]$ & $\uparrow[159], \sim[104,110]$ \\
\hline $\begin{array}{l}\uparrow[28,44], \sim \\
{[25,27]}\end{array}$ & $\uparrow[95], \sim[93]$ & $\lg E$ & $\uparrow[15,123,189]$ & $\sim[86,104,106,107,109,110]$ \\
\hline$\uparrow[190]$ & $\sim[153]$ & $\lg G$ & $\sim[123,189]$ & $\sim[86,104,106,107,109,110]$ \\
\hline Human & Mouse & $\begin{array}{l}\text { EFFECTS IN ALLERGIC } \\
\text { DISEASE }\end{array}$ & Human & Mouse \\
\hline$\overline{-}$ & $f[73], \uparrow[63,73], \sim[71]$ & GM-CSF & $\uparrow^{*}[168,169], \sim[165]$ & $\uparrow[85], \downarrow[107]$ \\
\hline$\overline{\uparrow[173]}$ & $\uparrow[70,89,93]$ & Eotaxin & $\cdot$ & $\uparrow[85,88,111,112]$ \\
\hline$\overline{\uparrow[46]}$ & $\uparrow[63,72,90], \downarrow[70,73]$ & Neutrophil number & $\uparrow[166], \sim[17]$ & $\uparrow[104-106,108,110,112]$ \\
\hline$\overline{\downarrow[191]}$ & $\uparrow[64,72,73,93,94,192], \downarrow[70,92]$ & $\begin{array}{l}\text { T or B-lymphocyte } \\
\text { number }\end{array}$ & $\uparrow$ 个[193], [17] & $\uparrow[84,85,104,105,108-111]$ \\
\hline$\downarrow[173,194]$ & $\begin{array}{l}\uparrow[63-65,68,69,71-73,89,94], \\
\downarrow[70,96], \sim[92]\end{array}$ & Eosinophil number & $\sim[17]$ & $\uparrow[83,85,87,88,104-106,109-111]$ \\
\hline$\overline{-}$ & $\downarrow[96]$ & T- or B-cell proliferation & $\uparrow[193]$ & $\uparrow[76,77,79,84,131]$ \\
\hline$\downarrow[191]$ & $\uparrow[71-73,93,94], \downarrow[70]$ & Dendritic cell number & $\cdot$ & $\cdot$ \\
\hline$\overline{-}$ & $\uparrow[72]$ & $\begin{array}{l}\text { Costimulatory molecule } \\
\text { expression }\end{array}$ & $\uparrow \uparrow[195]$ & $\uparrow[84,131]$ \\
\hline$\overline{\uparrow[194]}$ & $\uparrow[90]$ & Mast cell number & $\uparrow[166]$ & $\uparrow[108]$ \\
\hline$\uparrow[29]$ & $\uparrow[64,70], \downarrow[96]$ & $\mathrm{IL}-4$ & $\uparrow[55,123,193]$ & $\uparrow[76-78,84,131], \downarrow[107]$ \\
\hline$\uparrow[29], \downarrow[173]$ & $\uparrow[63,65,68,70,71,73,89], \downarrow[96]$ & $\mathrm{IL}-5$ & $\uparrow[85,123]$ & $\uparrow[85,88,104-107,109-112,131]$ \\
\hline$\uparrow[29]$ & $\uparrow[65,70,72]$ & IL-13 & $\uparrow[123]$ & $\uparrow[112,131]$ \\
\hline$\uparrow[29,44]$ & $\begin{array}{l}\uparrow[63-65,71,73,93], \sim \\
{[67-70,90,92,94]}\end{array}$ & $\lg \mathrm{E}$ & $\uparrow[15,55,56,123]$ & $\uparrow[174-84,86,87,104,105,107,108], \sim[106,110]$ \\
\hline $\bar{\cdot}$ & $\uparrow[63-65,71,73], \downarrow[96]$ & $\operatorname{lgG}$ & $\uparrow[56,123], \sim[55]$ & $\begin{array}{l}\uparrow[81,82,84-86,88,104,105,107-109,111,112], \\
\sim[106,110]\end{array}$ \\
\hline$\overline{\uparrow[29]}$ & $\cdot$ & Histamine & $\uparrow[15,196]$ & $\cdot$ \\
\hline$\uparrow[30,32]$ & $\begin{array}{l}\uparrow[66,68,68,69,89-91,93], \sim \\
{[67,71], \downarrow[70,92]}\end{array}$ & $\begin{array}{l}\text { Airway } \\
\text { hyperresponsiveness }\end{array}$ & $\uparrow[15,17,59]$ & $\uparrow[105-108]$ \\
\hline$\uparrow[194]$ & $\uparrow[89,90], \sim[95]$ & Airway wall remodeling & $\cdot$ & $\uparrow[110]$ \\
\hline$\uparrow[194]$ & $\uparrow[72,73,89,90], \downarrow[70]$ & Goblet cell hyperplasia & . & $\uparrow[83,85,87,106-108,110,111]$ \\
\hline
\end{tabular}

$\because:$ not described; $\uparrow:$ increased; $\sim$ : no effect; $\downarrow$ : decreased; *: in vitro data; $f$ : functional involvement 


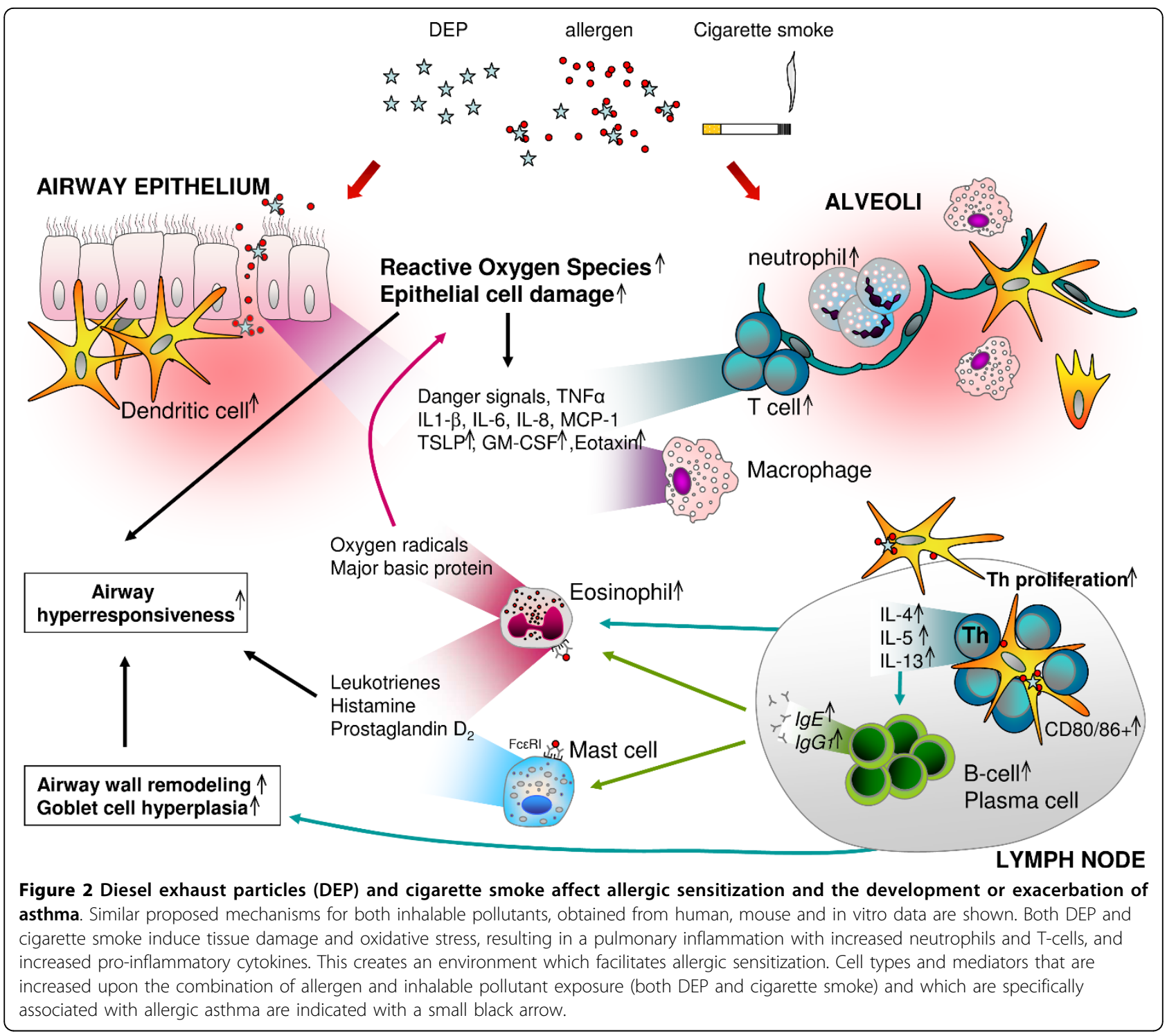

which inhalable pollutant exposure could affect asthma pathogenesis which merit further investigation [124]. The release of Damage Associated Molecular Patterns (DAMPs) upon inhalable pollutant exposure could play an important role in the asthma pathogenesis. DAMPs are danger signals that can be actively or passively released upon tissue damage or cellular stress. Several of these molecules can stimulate DC maturation and thus act as endogenous adjuvants, such as high mobility group box 1 (HMGB1) protein, heat shock proteins (HSP), adenosine-triphosphate (ATP) and uric acid [124]. The induction of somatic mutations by oxidative DNA damage in lung epithelial barrier cells is also a danger signal that could lead to DC polarization [132]. The activation of the inflammasomes, major intracellular immune response systems that sense danger, is an interesting pathway for future research [133]. Toll-like receptor signalling, which is activated upon recognition of Pathogen Associated Molecular Patterns (PAMPs) such as LPS, microbial sugars or DNA or RNA is another possible mechanism. For TLR4 it has been demonstrated that it is involved in pulmonary inflammation induced by tobacco smoke and DEP as such $[134,135]$. In a model of allergic sensitization induced by tobacco smoke exposure, however, both TLR4 and MyD88 appeared not to be required [72]. Recently, a role for TLR9 in an ETS/OVA model was reported [136]. It is of great interest to elucidate the putative pathways further and to determine if and at what level tobacco smoke and DEP show discrepant effects in their ability to induce and aggravate allergic inflammation. 


\section{Relevance of data from murine research: pro/con of mouse models}

In general, the observed effects of ETS, MS and DEP on the development and aggravation of allergic inflammation in mice correspond well with the observations in asthma patients. The clinical findings for DEP are strongly supported by data obtained in mouse experimental models. In the case of ETS and MS, both clinical findings and mouse data indicate that the relationship between smoke exposure and allergic sensitization and development of clinical asthma is less convincing than for DEP.

Mouse models have several limitations which should be considered when the effects of inhaled pollutant exposure on allergic inflammation are investigated [4,137,138]: i) Mice do not spontaneously develop asthma. ii) The frequently used model-allergen OVA has little biological relevance. However, aggravating effects of pollutant exposure can also be demonstrated in house dust mite models or models without intraperitoneal injections. iii) There are considerable differences in human and mouse immunology $[4,137,138]$. Species differences in number and size of the alveolar macrophages, for example, can affect the efficiency of alveolar clearance. iiii) Differences in respiratory physiology and pharmacology can have implications in view of the effects of exposure to inhalational pollutants. Mice are obligate nose breathers, incapable of mouth breathing. The oral breathing in humans bypasses the effective air cleaning capacity of the nose. Mice have lower number of cilia, fewer Clara cells and restriction of submucosal glands to the trachea resulting in a different filtering of inhaled particles compared to man [101]. This can have an impact on the distribution of inhaled particles throughout the respiratory tract $[139,140]$. Mice furthermore do not have a cough reflex and many mediators such as histamine and tachykinins have different pharmacological effects in humans, which complicates mechanistic analysis of the effects of inhaled pollutants on bronchial hyperresponsiveness [101,138]. iiiii) Finally, also anatomical and developmental differences can be important. Differences in pulmonary lobulation and bronchial branching (six airway generations in mice versus 23 airway generations in humans), which are already present during the embryonic stage of lung development, can affect particle distribution [139]. In this view, the anatomical location of specific pathological mechanisms induced by particles, such as remodeling, might be different in mice compared to man. In contrast to humans, rodents also do not have respiratory bronchioles. This results in a faster alveolar clearance in rodents, since bronchioles impede rapid clearance of particles from the alveoli.
Species differences may become particularly important in studies on the effects of inhaled pollutant exposure on asthma development early in life. Lung development encompasses different phases of cellular differentiation, branching morphogenesis and overall lung growth, which each can be differently affected depending on the timing of inhaled pollutant exposure [141]. Although the rodent and human respiratory system go across identical phases of development, the timing of each phase is markedly different. In humans, lung growth is essentially complete by the end of adolescence, whereas mouse lungs are more fully developed at birth, implicating that effects of postnatal pollutant exposure in both species cannot be directly compared [142].

However, despite these concerns, rodent models are a valuable tool to test hypotheses which are generated by epidemiological research $[4,138]$ and give more insights in how inhaled pollutant exposure can induce asthma development. i) Mouse models mimic important features of asthma, such as the pulmonary inflammation, remodelling and airway hyperresponsiveness, so the impact of inhaled pollutants on these features can be easily evaluated (Table 1). ii) Important analogies concerning the effects of in utero exposures are reported. For example, maternal smoking induces airway remodelling in mice offspring [90], which mimics increased lung remodelling due to in utero smoke exposure in children who died from sudden infant death syndrome [143]. Also effects of perinatal ETS exposure on the development of pulmonary function decrements in children can be well modelled in rats [141]. iii) Some important, but more general, advantages of using mouse asthma models are the relatively low cost, the availability of different inbred strains with different immunologic and physiologic properties, the numerous tools for experimental studies, the availability of the complete DNA sequence, and the existence of genetically modified strains [138]. Mice can thus be used for mechanistic studies that are not possible in humans due to ethical reasons. Such mechanistic studies, e.g. using genetically modified mice, are essential for elucidating the contribution of specific mediators or cell types (e.g. dendritic cells).

Mouse models can provide us with a biological basis for the observed associations between air pollution and allergic asthma in humans. They should of course mimic the clinical observations as closely as possible. Distinguishing between sensitization, development and aggravation and carefully selecting the appropriate models to answer specific research questions are therefore essential in studying the impact of inhalable pollutants on the pathogenesis of asthma. 


\section{Conclusions}

Exposure to inhalable pollutants is an important factor which affects sensitization, development and aggravation of asthma. Although clinical and epidemiological studies provide direct indications about the importance of inhaled pollutants in the pathogenesis of asthma, data from mice hold promise to provide mechanistic clues. We here reviewed the excess of mouse models that are available, focusing on unmet needs that would allow determining the critical mediators involved in the effects of the aforementioned pollutants on the different stages of the disease.

\section{Additional file 1: Table 2: Effects of environmental tobacco smoke (ETS) on murine allergic sensitization. Table 2 provides a detailed overview of methodologies and results from murine models that examine the effects of ETS on allergic sensitization \\ Click here for file \\ [ http://www.biomedcentral.com/content/supplementary/1465-9921-11-7-} S1.PDF ]

Additional file 2: Table 3: Effects of mainstream cigarette smoke (MS) on murine allergic sensitization. Table 3 provides a detailed overview of methodologies and results from murine models that examine the effects of MS on allergic sensitization

Click here for file

[ http://www.biomedcentral.com/content/supplementary/1465-9921-11-7S2.PDF ]

Additional file 3: Table 4: Effects of diesel exhaust particles (DEP) on murine allergic sensitization. Table 4 provides a detailed overview of methodologies and results from murine models that examine the effects of DEP on allergic sensitization

Click here for file

[http://www.biomedcentral.com/content/supplementary/1465-9921-11-7S3.PDF ]

Additional file 4: Table 5: Effects of environmental tobacco smoke (ETS) on development or aggravation of asthma in murine models Table 5 provides a detailed overview of methodologies and results from murine models that examine the effects of ETS on development or aggravation of asthma

Click here for file

[http://www.biomedcentral.com/content/supplementary/1465-9921-11-7S4.PDF ]

Additional file 5: Table 6: Effects of mainstream cigarette smoke (MS) on development or aggravation of asthma in murine models. Table 6 provides a detailed overview of methodologies and results from murine models that examine the effects of MS on development or aggravation of asthma

Click here for file

[ http://www.biomedcentral.com/content/supplementary/1465-9921-11-7S5.PDF ]

Additional file 6: Table 7: Effects of diesel exhaust particles (DEP) on development or aggravation of asthma in murine models. Table 7 provides a detailed overview of methodologies and results from murine models that examine the effects of DEP on development or aggravation of asthma

Click here for file

[http://www.biomedcentral.com/content/supplementary/1465-9921-11-7S6.PDF ]

\section{Acknowledgements}

This work is sponsored by the Interuniversity Attraction Poles Program (Belgian State, Belgian Science Policy, Project P6/35) and by the Fund for Scientific Research - Flanders (FWO-Vlaanderen - Project G.0052.06). K. Tournoy is a senior clinical investigator and J. Vanoirbeek is a post-doctoral fellow granted by FWO Flanders. D. Cataldo is supported by the FNRS-FRS, and received grants from the Walloon Region Governement.

\section{Author details}

${ }^{1}$ Laboratory for Translational Research in Obstructive Pulmonary Diseases, Department of Respiratory Medicine, Ghent University Hospital, De Pintelaan 185, 9000 Ghent, Belgium. 'Laboratory of Tumours and Developmental Biology, GIGA-research, University of Liège and CHU of Liège, Liège, Belgium. ${ }^{3}$ Department of Pneumology, GIGA-research, University of Liège and CHU of Liège, Liège, Belgium. ${ }^{4}$ Laboratory of Pneumology, Research Unit of Lung Toxicology, K.U.Leuven, Leuven, Belgium.

\section{Authors' contributions}

TM and SP performed the literature search and collected all relevant publications. TM drafted the manuscript. TM and EL designed the figures. GJ, $\mathrm{KT}$ and DC assisted with the design of the review. All authors helped to draft the manuscript and critically read and approved the final manuscript.

\section{Competing interests}

The authors declare that they have no competing interests.

Received: 29 September 2009

Accepted: 21 January 2010 Published: 21 January 2010

\section{References}

1. Global Initiative for Asthma: Global strategy for asthma management and prevention: updated 2006. 2008http://www.ginasthma.org.

2. Eder W, Ege MJ, von Mutius E: The asthma epidemic. N Engl J Med 2006, 355:2226-2235.

3. Umetsu DT, McIntire JJ, Akbari O, Macaubas C, DeKruyff RH: Asthma: an epidemic of dysregulated immunity. Nat Immunol 2002, 3:715-720.

4. Zosky GR, Sly PD: Animal models of asthma. Clin Exp Allergy 2007, 37:973-988.

5. World Health Organisation - IARC: Tobacco Smoking and Tobacco Smoke, Summary of Data Reported and Evaluation. Evaluation 2007, Chapter 5.5:83.

6. Stedman RL: The chemical composition of tobacco and tobacco smoke. Chem Rev 1968, 68:153-207.

7. Swauger JE, Steichen TJ, Murphy PA, Kinsler S: An analysis of the mainstream smoke chemistry of samples of the U.S. cigarette market acquired between 1995 and 2000. Regul Toxicol Pharmacol 2002, 35:142-156.

8. Thielen A, Klus $\mathrm{H}$, Muller L: Tobacco smoke: Unraveling a controversial subject. Exp Toxicol Pathol 2008, 60(2-3):141-156.

9. Hogg JC, Chu F, Utokaparch S, Woods R, Elliott WM, Buzatu L, Cherniack RM, Rogers RM, Sciurba FC, Coxson HO, Pare PD: The nature of small-airway obstruction in chronic obstructive pulmonary disease. $N$ Engl J Med 2004, 350:2645-2653.

10. Aoshiba K, Nagai A: Differences in airway remodeling between asthma and chronic obstructive pulmonary disease. Clin Rev Allergy Immunol 2004, 27:35-43.

11. World Health Organisation: Air quality guidelines for particulate matter, ozone, nitrogen dioxide and sulfur dioxide. Global update Summary of risk assessment 2005http://whqlibdoc.who.int/hq/2006/ WHO SDE PHE OEH 06.02 eng.pdf.

12. Salvi $\bar{S}$, Holgate ST: Mechanisms of particulate matter toxicity. Clin Exp Allergy 1999, 29:1187-1194.

13. Wichmann HE: Diesel exhaust particles. Inhal Toxicol 2007, 19(Suppl 1):241-244.

14. Sydbom A, Blomberg A, Parnia S, Stenfors N, Sandstrom T, Dahlen SE: Health effects of diesel exhaust emissions. Eur Respir J 2001, 17:733-746.

15. Riedl M, Diaz-Sanchez D: Biology of diesel exhaust effects on respiratory function. J Allergy Clin Immunol 2005, 115:221-228.

16. Majo J, Ghezzo H, Cosio MG: Lymphocyte population and apoptosis in the lungs of smokers and their relation to emphysema. Eur Respir J 2001, 17:946-953.

17. Stenfors N, Nordenhall C, Salvi SS, Mudway I, Soderberg M, Blomberg A, Helleday R, Levin JO, Holgate ST, Kelly FJ, Frew AJ, Sandstrom T: Different airway inflammatory responses in asthmatic and healthy humans exposed to diesel. Eur Respir J 2004, 23:82-86. 
18. Kuschner WG, D'Alessandro A, Wong H, Blanc PD: Dose-dependent cigarette smoking-related inflammatory responses in healthy adults. Eur Respir J 1996, 9:1989-1994.

19. Hodge S, Hodge G, Ahern J, Jersmann H, Holmes M, Reynolds PN: Smoking alters alveolar macrophage recognition and phagocytic ability: implications in chronic obstructive pulmonary disease. Am J Respir Cell Mol Biol 2007, 37:748-755.

20. Bousquet J, Vignola AM: Exposure to environmental tobacco smoke and adult asthma. Allergy 2001, 56:466-469.

21. von Mutius E: Environmental factors influencing the development and progression of pediatric asthma. J Allergy Clin Immunol 2002, 109: S525-S532.

22. Skorge TD, Eagan TM, Eide GE, Gulsvik A, Bakke PS: The adult incidence of asthma and respiratory symptoms by passive smoking in uterus or in childhood. Am J Respir Crit Care Med 2005, 172:61-66.

23. Cook DG, Strachan DP: Health effects of passive smoking. 3. Parental smoking and prevalence of respiratory symptoms and asthma in school age children. Thorax 1997, 52:1081-1094.

24. Larsson ML, Frisk M, Hallstrom J, Kiviloog J, Lundback B: Environmental tobacco smoke exposure during childhood is associated with increased prevalence of asthma in adults. Chest 2001, 120:711-717.

25. Janson C, Chinn S, Jarvis D, Zock JP, Toren K, Burney P: Effect of passive smoking on respiratory symptoms, bronchial responsiveness, lung function, and total serum IgE in the European Community Respiratory Health Survey: a cross-sectional study. Lancet 2001, 358:2103-2109.

26. Larsson ML, Loit HM, Meren M, Polluste J, Magnusson A, Larsson K, Lundback B: Passive smoking and respiratory symptoms in the FinEsS Study. Eur Respir J 2003, 21:672-676.

27. Strachan DP, Cook DG: Health effects of passive smoking. 5. Parental smoking and allergic sensitisation in children. Thorax 1998, 53:117-123.

28. Lannero E, Wickman M, van Hage M, Bergstrom A, Pershagen G, Nordvall L: Exposure to environmental tobacco smoke and sensitisation in children. Thorax 2008, 63:172-176.

29. Diaz-Sanchez D, Rumold R, Gong H Jr: Challenge with environmental tobacco smoke exacerbates allergic airway disease in human beings. $J$ Allergy Clin Immunol 2006, 118:441-446.

30. Coultas DB: Health effects of passive smoking. 8. Passive smoking and risk of adult asthma and COPD: an update. Thorax 1998, 53:381-387.

31. Eisner MD, Yelin EH, Katz PP, Earnest G, Blanc PD: Exposure to indoor combustion and adult asthma outcomes: environmental tobacco smoke, gas stoves, and woodsmoke. Thorax 2002, 57:973-978.

32. Joad JP: Smoking and pediatric respiratory health. Clin Chest Med 2000, 21:37-46, vii-viii..

33. Mannino DM, Homa DM, Redd SC: Involuntary smoking and asthma severity in children: data from the Third National Health and Nutrition Examination Survey. Chest 2002, 122:409-415.

34. Tatum AJ, Shapiro GG: The effects of outdoor air pollution and tobacco smoke on asthma. Immunol Allergy Clin North Am 2005, 25:15-30.

35. Siroux V, Pin I, Oryszczyn MP, Le Moual N, Kauffmann F: Relationships of active smoking to asthma and asthma severity in the EGEA study. Epidemiological study on the Genetics and Environment of Asthma. Eur Respir J 2000, 15:470-477.

36. Piipari R, Jaakkola JJ, Jaakkola N, Jaakkola MS: Smoking and asthma in adults. Eur Respir J 2004, 24:734-739.

37. Lundback B, Ronmark E, Jonsson E, Larsson K, Sandstrom T: Incidence of physician-diagnosed asthma in adults-a real incidence or a result of increased awareness? Report from The Obstructive Lung Disease in Northern Sweden Studies. Respir Med 2001, 95:685-692.

38. Gilliland FD, Islam T, Berhane K, Gauderman WJ, McConnell R, Avol E, Peters JM: Regular Smoking and Asthma Incidence in Adolescents. Am J Respir Crit Care Med 2006, 174:1094-100.

39. Genuneit J, Weinmayr G, Radon K, Dressel H, Windstetter D, Rzehak P, Vogelberg C, Leupold W, Nowak D, von Mutius E, Weiland SK: Smoking and the incidence of asthma during adolescence: results of a large cohort study in Germany. Thorax 2006, 61:572-578.

40. Avila L, Soto-Martinez ME, Soto-Quiros ME, Celedon JC: Asthma, current wheezing, and tobacco use among adolescents and young adults in Costa Rica. J Asthma 2005, 42:543-547.

41. Kim YK, Kim SH, Tak YJ, Jee YK, Lee BJ, Kim SH, Park HW, Jung JW, Bahn JW, Chang YS, Choi DC, Chang SI, Min KU, Kim YY, Cho SH: High prevalence of current asthma and active smoking effect among the elderly. Clin Exp Allergy 2002, 32:1706-1712.

42. Annesi-Maesano I, Oryszczyn MP, Raherison C, Kopferschmitt C, Pauli G, Taytard A, Tunon de Lara M, Vervloet D, Charpin D: Increased prevalence of asthma and allied diseases among active adolescent tobacco smokers after controlling for passive smoking exposure. A cause for concern?. Clin Exp Allergy 2004, 34:1017-1023.

43. Miyake Y, Miyamoto S, Ohya Y, Sasaki S, Matsunaga I, Yoshida T, Hirota Y, Oda $\mathrm{H}$ : Association of active and passive smoking with allergic disorders in pregnant Japanese women: baseline data from the Osaka Maternal and Child Health Study. Ann Allergy Asthma Immunol 2005, 94:644-651.

44. Oryszczyn MP, Annesi-Maesano I, Charpin D, Paty E, Maccario J, Kauffmann F: Relationships of active and passive smoking to total lgE in adults of the Epidemiological Study of the Genetics and Environment of Asthma, Bronchial Hyperresponsiveness, and Atopy (EGEA). Am J Respir Crit Care Med 2000, 161:1241-1246.

45. Chaudhuri R, McSharry C, McCoard A, Livingston E, Hothersall E, Spears M, Lafferty J, Thomson NC: Role of symptoms and lung function in determining asthma control in smokers with asthma. Allergy 2008, 63:132-135.

46. Boulet LP, Lemiere C, Archambault F, Carrier G, Descary MC, Deschesnes F: Smoking and asthma: clinical and radiologic features, lung function, and airway inflammation. Chest 2006, 129:661-668.

47. James AL, Palmer LJ, Kicic E, Maxwell PS, Lagan SE, Ryan GF, Musk AW: Decline in lung function in the Busselton Health Study: the effects of asthma and cigarette smoking. Am J Respir Crit Care Med 2004, 171:109-114.

48. Beeh KM, Micke P, Ksoll M, Buhl R: Cigarette smoking, but not sensitization to Alternaria, is associated with severe asthma in urban patients. J Asthma 2001, 38:41-49.

49. Thomson NC, Spears M: The influence of smoking on the treatment response in patients with asthma. Curr Opin Allergy Clin Immunol 2005 5:57-63.

50. Braback L, Forsberg B: Does traffic exhaust contribute to the development of asthma and allergic sensitization in children: findings from recent cohort studies. Environ Health 2009, 8:17.

51. Heinrich J, Wichmann HE: Traffic related pollutants in Europe and their effect on allergic disease. Curr Opin Allergy Clin Immunol 2004, 4:341-348.

52. Polosa R, Salvi S, Di Maria GU: Allergic susceptibility associated with diesel exhaust particle exposure: clear as mud. Arch Environ Health 2002, 57:188-193.

53. Morgenstern V, Zutavern A, Cyrys J, Brockow I, Koletzko S, Kramer U, Behrendt H, Herbarth O, von Berg A, Bauer CP, Wichmann HE, Heinrich J: Atopic diseases, allergic sensitization, and exposure to traffic-related air pollution in children. Am J Respir Crit Care Med 2008, 177:1331-1337.

54. Nordling E, Berglind N, Melen E, Emenius G, Hallberg J, Nyberg F, Pershagen G, Svartengren M, Wickman M, Bellander T: Traffic-related air pollution and childhood respiratory symptoms, function and allergies. Epidemiology 2008, 19:401-408.

55. Diaz-Sanchez D, Garcia MP, Wang M, Jyrala M, Saxon A: Nasal challenge with diesel exhaust particles can induce sensitization to a neoallergen in the human mucosa. J Allergy Clin Immunol 1999, 104:1183-1188.

56. Diaz-Sanchez D, Tsien A, Fleming J, Saxon A: Combined diesel exhaust particulate and ragweed allergen challenge markedly enhances human in vivo nasal ragweed-specific IgE and skews cytokine production to a $\mathrm{T}$ helper cell 2-type pattern. J Immunol 1997, 158:2406-2413.

57. Boezen M, Schouten J, Rijcken B, Vonk J, Gerritsen J, Zee van der S, Hoek G, Brunekreef B, Postma D: Peak expiratory flow variability, bronchial responsiveness, and susceptibility to ambient air pollution in adults. Am J Respir Crit Care Med 1998, 158:1848-1854.

58. Holguin F: Traffic, outdoor air pollution, and asthma. Immunol Allergy Clin North Am 2008, 28:577-588.

59. Nordenhall C, Pourazar J, Ledin MC, Levin JO, Sandstrom T, Adelroth E: Diesel exhaust enhances airway responsiveness in asthmatic subjects. Eur Respir J 2001, 17:909-915.

60. McCreanor J, Cullinan P, Nieuwenhuijsen MJ, Stewart-Evans J, Malliarou E, Jarup L, Harrington R, Svartengren M, Han IK, Ohman-Strickland P, Chung KF, Zhang J: Respiratory effects of exposure to diesel traffic in persons with asthma. N Engl J Med 2007, 357:2348-2358.

61. Holt PG, Batty JE, Turner KJ: Inhibition of specific IgE responses in mice by pre-exposure to inhaled antigen. Immunology 1981, 42:409-417. 
62. Seymour BW, Gershwin LJ, Coffman RL: Aerosol-induced immunoglobulin (Ig)-E unresponsiveness to ovalbumin does not require CD8+ or T cell receptor (TCR)-gamma/delta+ T cells or interferon (IFN)-gamma in a murine model of allergen sensitization. J Exp Med 1998, 187:721-731.

63. Rumold $R$, Jyrala M, Diaz-Sanchez D: Secondhand smoke induces allergic sensitization in mice. J Immunol 2001, 167:4765-4770.

64. Seymour BW, Pinkerton KE, Friebertshauser KE, Coffman RL, Gershwin LJ: Second-hand smoke is an adjuvant for T helper-2 responses in a murine model of allergy. J Immunol 1997, 159:6169-6175.

65. Seymour BW, Friebertshauser KE, Peake JL, Pinkerton KE, Coffman RL, Gershwin $\sqcup:$ Gender differences in the allergic response of mice neonatally exposed to environmental tobacco smoke. Dev Immunol 2002, 9:47-54.

66. Barrett EG, Wilder JA, March TH, Espindola T, Bice DE: Cigarette smokeinduced airway hyperresponsiveness is not dependent on elevated immunoglobulin and eosinophilic inflammation in a mouse model of allergic airway disease. Am J Respir Crit Care Med 2002, 165:1410-1418.

67. Bowles K, Horohov D, Paulsen D, Leblanc C, Littlefield-Chabaud M, Ahlert T, Ahlert K, Pourciau S, Penn A: Exposure of adult mice to environmental tobacco smoke fails to enhance the immune response to inhaled antigen. Inhal Toxicol 2005, 17:43-51.

68. Penn AL, Rouse RL, Horohov DW, Kearney MT, Paulsen DB, Lomax L: In utero exposure to environmental tobacco smoke potentiates adult responses to allergen in BALB/c mice. Environ Health Perspect 2007, 115:548-555.

69. Seymour BW, Schelegle ES, Pinkerton KE, Friebertshauser KE, Peake JL, Kurupd VP, Coffman RL, Gershwin LJ: Second-hand smoke increases bronchial hyperreactivity and eosinophilia in a murine model of allergic aspergillosis. Clin Dev Immunol 2003, 10:35-42

70. Robbins CS, Pouladi MA, Fattouh R, Dawe DE, Vujicic N, Richards CD, Jordana M, Inman MD, Stampfli MR: Mainstream cigarette smoke exposure attenuates airway immune inflammatory responses to surrogate and common environmental allergens in mice, despite evidence of increased systemic sensitization. J Immunol 2005, 175:2834-2842.

71. Moerloose KB, Robays LJ, Maes T, Brusselle GG, Tournoy KG, Joos GF: Cigarette smoke exposure facilitates allergic sensitization in mice. Respir Res 2006, 7:49.

72. Robays LJ, Lanckacker EA, Moerloose KB, Maes T, Bracke KR, Brusselle GG, Joos GF, Vermaelen KY: Concomitant inhalation of cigarette smoke and aerosolized protein activates airway dendritic cells and induces allergic airway inflammation in a TLR-independent way. J Immunol 2009, 183:2758-2766.

73. Trimble NJ, Botelho FM, Bauer CM, Fattouh R, Stampfli MR: Adjuvant and anti-inflammatory properties of cigarette smoke in murine allergic airway inflammation. Am J Respir Cell Mol Biol 2009, 40:38-46.

74. Muranaka M, Suzuki S, Koizumi K, Takafuji S, Miyamoto T, Ikemori R, Tokiwa H: Adjuvant activity of diesel-exhaust particulates for the production of IgE antibody in mice. J Allergy Clin Immunol 1986, 77:616-623.

75. Takafuji S, Suzuki S, Koizumi K, Tadokoro K, Miyamoto T, Ikemori R, Muranaka M: Diesel-exhaust particulates inoculated by the intranasal route have an adjuvant activity for IgE production in mice. J Allergy Clin Immunol 1987, 79:639-645.

76. Fujimaki H, Nohara O, Ichinose T, Watanabe N, Saito S: IL-4 production in mediastinal lymph node cells in mice intratracheally instilled with diesel exhaust particulates and antigen. Toxicology 1994, 92:261-268.

77. Fujimaki H, Saneyoshi K, Nohara O, Shiraishi F, Imai T: Intranasal instillation of diesel exhaust particulates and antigen in mice modulated cytokine productions in cervical lymph node cells. Int Arch Allergy Immunol 1995, 108:268-273.

78. Fujimaki H, Saneyoshi K, Shiraishi F, Imai T, Endo T: Inhalation of diesel exhaust enhances antigen-specific IgE antibody production in mice. Toxicology 1997, 116:227-233.

79. Lovik M, Hogseth AK, Gaarder PI, Hagemann R, Eide I: Diesel exhaust particles and carbon black have adjuvant activity on the local lymph node response and systemic lgE production to ovalbumin. Toxicology 1997, 121:165-178

80. Nilsen A, Hagemann R, Eide I: The adjuvant activity of diesel exhaust particles and carbon black on systemic IgE production to ovalbumin in mice after intranasal instillation. Toxicology 1997, 124:225-232.
81. Heo Y, Saxon A, Hankinson O: Effect of diesel exhaust particles and their components on the allergen-specific $\lg E$ and $\lg G 1$ response in mice. Toxicology 2001, 159:143-158.

82. Suzuki T, Kanoh T, Ishimori M, Ikeda S, Ohkuni H: Adjuvant activity of diesel exhaust particulates (DEP) in production of anti-lgE and anti-lgG1 antibodies to mite allergen in mice. J Clin Lab Immunol 1996, 48:187-199.

83. Ichinose T, Takano H, Miyabara Y, Yanagisawa R, Sagai M: Murine strain differences in allergic airway inflammation and immunoglobulin production by a combination of antigen and diesel exhaust particles. Toxicology 1997, 122:183-192.

84. van Zijverden $M$, Pijl van der A, Bol M, van Pinxteren FA, de Haar C, Penninks AH, Van Loveren H, Pieters R: Diesel exhaust, carbon black, and silica particles display distinct Th1/Th2 modulating activity. Toxicol Appl Pharmacol 2000, 168:131-139.

85. Sadakane K, Ichinose T, Takano H, Yanagisawa R, Sagai M, Yoshikawa T, Shibamoto T: Murine strain differences in airway inflammation induced by diesel exhaust particles and house dust mite allergen. Int Arch Allergy Immunol 2002, 128:220-228.

86. Whitekus MJ, Li N, Zhang M, Wang M, Horwitz MA, Nelson SK, Horwitz LD, Brechun N, Diaz-Sanchez D, Nel AE: Thiol antioxidants inhibit the adjuvant effects of aerosolized diesel exhaust particles in a murine model for ovalbumin sensitization. J Immunol 2002, 168:2560-2567.

87. Steerenberg PA, van Dalen WJ, Withagen CE, Dormans JA, Van Loveren H: Optimization of route of administration for coexposure to ovalbumin and particle matter to induce adjuvant activity in respiratory allergy in the mouse. Inhal Toxicol 2003, 15:1309-1325.

88. Ichinose T, Takano H, Sadakane K, Yanagisawa R, Yoshikawa T, Sagai M, Shibamoto T: Mouse strain differences in eosinophilic airway inflammation caused by intratracheal instillation of mite allergen and diesel exhaust particles. J Appl Toxicol 2004, 24:69-76.

89. Min MG, Song DJ, Miller M, Cho JY, McElwain S, Ferguson P, Broide DH: Coexposure to environmental tobacco smoke increases levels of allergen-induced airway remodeling in mice. J Immunol 2007, 178:5321-5328.

90. Blacquiere MJ, Timens W, Melgert BN, Geerlings M, Postma DS, Hylkema MN: Maternal smoking during pregnancy induces airway remodelling in mice offspring. Eur Respir J 2009, 33:1133-1140.

91. Singh SP, Barrett EG, Kalra R, Razani-Boroujerdi S, Langley RJ, Kurup V, Tesfaigzi Y, Sopori ML: Prenatal cigarette smoke decreases lung CAMP and increases airway hyperresponsiveness. Am J Respir Crit Care Med 2003, 168:342-347.

92. Melgert BN, Postma DS, Geerlings M, Luinge MA, Klok PA, Strate Van Der BW, Kerstjens HA, Timens W, Hylkema MN: Short-term smoke exposure attenuates ovalbumin-induced airway inflammation in allergic mice. Am J Respir Cell Mol Biol 2004, 30:880-885.

93. Moerloose KB, Pauwels RA, Joos GF: Short-term cigarette smoke exposure enhances allergic airway inflammation in mice. Am J Respir Crit Care Med 2005, 172:168-172

94. Van Hove CL, Moerloose K, Maes T, Joos GF, Tournoy KG: Cigarette smoke enhances Th-2 driven airway inflammation and delays inhalational tolerance. Respir Res 2008, 9:42.

95. Melgert BN, Timens W, Kerstjens HA, Geerlings M, Luinge MA, Schouten JP, Postma DS, Hylkema MN: Effects of 4 months of smoking in mice with ovalbumin-induced airway inflammation. Clin Exp Allergy 2007, 37:1798-1808.

96. Thatcher TH, Benson RP, Phipps RP, Sime PJ: High dose but not low dose mainstream cigarette smoke suppresses allergic airway inflammation by inhibiting T cell function. Am J Physiol Lung Cell Mol Physiol 2008, 295: L412-21.

97. Chapman JT, Otterbein LE, Elias JA, Choi AM: Carbon monoxide attenuates aeroallergen-induced inflammation in mice. Am J Physiol Lung Cell Mol Physiol 2001, 281:L209-L216.

98. Stampfli MR, Anderson GP: How cigarette smoke skews immune responses to promote infection, lung disease and cancer. Nat Rev Immunol 2009, 9:377-384.

99. Brusselle GG, Bracke KR, Maes T, D'hulst Al, Moerloose KB, Joos GF, Pauwels RA: Murine models of COPD. Pulm Pharmacol Ther 2005, 19:155-165.

100. Churg A, Cosio M, Wright JL: Mechanisms of cigarette smoke-induced COPD: insights from animal models. Am J Physiol Lung Cell Mol Physiol 2008, 294:L612-L631. 
101. Groneberg DA, Chung KF: Models of chronic obstructive pulmonary disease. Respir Res 2004, 5:18.

102. Bracke KR, D'hulst Al, Maes T, Moerloose KB, Demedts IK, Lebecque S, Joos GF, Brusselle GG: Cigarette Smoke-Induced Pulmonary Inflammation and Emphysema Are Attenuated in CCR6-Deficient Mice. J Immunol 2006, 177:4350-4359.

103. Demoor T, Bracke KR, Maes T, Vandooren B, Elewaut D, Pilette C, Joos GF, Brusselle GG: Role of lymphotoxin-alpha in cigarette smoke-induced inflammation and lymphoid neogenesis. Eur Respir J 2009, 34:405-416.

104. Takano H, Yoshikawa T, Ichinose T, Miyabara Y, Imaoka K, Sagai M: Diesel exhaust particles enhance antigen-induced airway inflammation and local cytokine expression in mice. Am J Respir Crit Care Med 1997, 156:36-42.

105. Takano H, Ichinose T, Miyabara Y, Yoshikawa T, Sagai M: Diesel exhaust particles enhance airway responsiveness following allergen exposure in mice. Immunopharmacol Immunotoxicol 1998, 20:329-336.

106. Miyabara Y, Ichinose T, Takano H, Lim HB, Sagai M: Effects of diesel exhaust on allergic airway inflammation in mice. J Allergy Clin Immunol 1998, 102:805-812

107. Miyabara Y, Takano H, Ichinose T, Lim HB, Sagai M: Diesel exhaust enhances allergic airway inflammation and hyperresponsiveness in mice. Am J Respir Crit Care Med 1998, 157:1138-1144.

108. Miyabara Y, Ichinose T, Takano H, Sagai M: Diesel exhaust inhalation enhances airway hyperresponsiveness in mice. Int Arch Allergy Immunol 1998, 116:124-131

109. Miyabara Y, Yanagisawa R, Shimojo N, Takano H, Lim HB, Ichinose T, Sagai M: Murine strain differences in airway inflammation caused by diesel exhaust particles. Eur Respir J 1998, 11:291-298.

110. Ichinose T, Takano H, Miyabara Y, Sagai M: Long-term exposure to diesel exhaust enhances antigen-induced eosinophilic inflammation and epithelial damage in the murine airway. Toxicol Sci 1998, 44:70-79.

111. Ichinose T, Takano H, Sadakane K, Yanagisawa R, Kawazato H, Sagai M, Shibamoto T: Differences in airway-inflammation development by house dust mite and diesel exhaust inhalation among mouse strains. Toxicol Appl Pharmacol 2003, 187:29-37.

112. Yanagisawa R, Takano H, Inoue Kl, Ichinose T, Sadakane K, Yoshino S, Yamaki K, Yoshikawa T, Hayakawa K: Components of diesel exhaust particles differentially affect Th1/Th2 response in a murine model of allergic airway inflammation. Clin Exp Allergy 2006, 36:386-395.

113. Matsumoto A, Hiramatsu K, Li Y, Azuma A, Kudoh S, Takizawa H, Sugawara I: Repeated exposure to low-dose diesel exhaust after allergen challenge exaggerates asthmatic responses in mice. Clin Immunol 2006, 121:227-235.

114. Hao M, Comier S, Wang M, Lee JJ, Nel A: Diesel exhaust particles exert acute effects on airway inflammation and function in murine allergen provocation models. J Allergy Clin Immunol 2003, 112:905-914.

115. Wu ZX, Zhou D, Chen G, Lee LY: Airway hyperresponsiveness to cigarette smoke in ovalbumin-sensitized guinea pigs. Am J Respir Crit Care Med 2000, 161:73-80.

116. Bergren DR: Tobacco smoke is an adjuvant for maintained airway sensitization in guinea pigs. J Asthma 2007, 44:723-728.

117. Steerenberg PA, Dormans JA, van Doorn CC, Middendorp S, Vos JG, Van Loveren $\mathrm{H}$ : A pollen model in the rat for testing adjuvant activity of air pollution components. Inhal Toxicol 1999, 11:1109-1122.

118. Dong CC, Yin XJ, Ma JY, Millecchia L, Wu ZX, Barger MW, Roberts JR, Antonini JM, Dey RD, Ma JK: Effect of diesel exhaust particles on allergic reactions and airway responsiveness in ovalbumin-sensitized brown Norway rats. Toxicol Sci 2005, 88:202-212.

119. Al-Humadi NH, Siegel PD, Lewis DM, Barger MW, Ma JY, Weissman DN, Ma JK: The effect of diesel exhaust particles (DEP) and carbon black (CB) on thiol changes in pulmonary ovalbumin allergic sensitized Brown Norway rats. Exp Lung Res 2002, 28:333-349.

120. Dong CC, Yin XJ, Ma JY, Millecchia L, Barger MW, Roberts JR, Zhang XD, Antonini JM, Ma JK: Exposure of brown Norway rats to diesel exhaust particles prior to ovalbumin (OVA) sensitization elicits IgE adjuvant activity but attenuates OVA-induced airway inflammation. Toxicol Sci 2005, 88:150-160.

121. Steerenberg PA, Withagen CE, Dormans JA, van Dalen WJ, Van Loveren $H$, Casee FR: Adjuvant activity of various diesel exhaust and ambient particles in two allergic models. J Toxicol Environ Health A 2003, 66:1421-1439
122. Singh P, Madden M, Gilmour Ml: Effects of diesel exhaust particles and carbon black on induction of dust mite allergy in brown norway rats. $J$ Immunotoxicol 2005, 2:41-49.

123. Pandya RJ, Solomon G, Kinner A, Balmes JR: Diesel exhaust and asthma: hypotheses and molecular mechanisms of action. Environ Health Perspect 2002, 110(Suppl 1):103-112.

124. Robays $L$, Maes T, Joos GF, Vermaelen KY: Between a cough and a wheeze: dendritic cells at the nexus of tobacco smoke-induced allergic airway sensitization. Mucosal Immunol 2009, 2:206-219.

125. Provoost S, Maes T, Willart MA, Joos GF, Lambrecht BN, Tournoy KG: Diesel exhaust particles stimulate adaptive immunity by acting on pulmonary dendritic cells. J Immunol 2010, 184(1):426-432.

126. Nakamura Y, Miyata M, Ohba T, Ando T, Hatsushika K, Suenaga F, Shimokawa N, Ohnuma Y, Katoh R, Ogawa H, Nakao A: Cigarette smoke extract induces thymic stromal lymphopoietin expression, leading to $T$ (H)2-type immune responses and airway inflammation. J Allergy Clin Immunol 2008, 122:1208-1214.

127. Bleck B, Tse DB, Curotto de Lafaille MA, Zhang F, Reibman J: Diesel exhaust particle-exposed human bronchial epithelial cells induce dendritic cell maturation and polarization via thymic stromal lymphopoietin. J Clin Immunol 2008, 28:147-156.

128. Bleck B, Tse DB, Jaspers I, Curotto de Lafaille MA, Reibman J: Diesel exhaust particle-exposed human bronchial epithelial cells induce dendritic cell maturation. J Immunol 2006, 176:7431-7437.

129. Hammad H, Lambrecht BN: Dendritic cells and epithelial cells: linking innate and adaptive immunity in asthma. Nat Rev Immunol 2008, 8:193-204.

130. Knox RB, Suphioglu C, Taylor P, Desai R, Watson HC, Peng JL, Bursill LA: Major grass pollen allergen Lol $p 1$ binds to diesel exhaust particles: implications for asthma and air pollution. Clin Exp Allergy 1997, 27:246-251.

131. Inoue K, Koike E, Takano H, Yanagisawa R, Ichinose T, Yoshikawa T: Effects of diesel exhaust particles on antigen-presenting cells and antigenspecific Th immunity in mice. Exp Biol Med (Maywood) 2009, 234:200-209.

132. Tzortzaki EG, Siafakas NM: A hypothesis for the initiation of COPD. Eur Respir I 2009, 34:310-315.

133. Martinon F, Mayor A, Tschopp J: The inflammasomes: guardians of the body. Annu Rev Immunol 2009, 27:229-265.

134. Maes T, Bracke KR, Vermaelen KY, Demedts IK, Joos GF, Pauwels RA, Brusselle GG: Murine TLR4 is implicated in cigarette smoke-induced pulmonary inflammation. Int Arch Allergy Immunol 2006, 141:354-368

135. Inoue K, Takano H, Yanagisawa R, Hirano S, Ichinose T, Shimada A, Yoshikawa T: The role of toll-like receptor 4 in airway inflammation induced by diesel exhaust particles. Arch Toxicol 2006, 80:275-279.

136. Song DJ, Min MG, Miller M, Cho JY, Yum HY, Broide DH: Toll-Like Receptor9 Agonist Inhibits Airway Inflammation, Remodeling and Hyperreactivity in Mice Exposed to Chronic Environmental Tobacco Smoke and Allergen. Int Arch Allergy Immunol 2009, 151:285-296.

137. Mestas J, Hughes CC: Of mice and not men: differences between mouse and human immunology. J Immunol 2004, 172:2731-2738.

138. Finkelman FD, Wills-Karp M: Usefulness and optimization of mouse models of allergic airway disease. J Allergy Clin Immunol 2008, 121:603-606

139. Phalen RF, Oldham MJ, Wolff RK: The relevance of animal models for aerosol studies. J Aerosol Med Pulm Drug Deliv 2008, 21:113-124.

140. Lippmann M, Schlesinger RB: Interspecies comparisons of particle deposition and mucociliary clearance in tracheobronchial airways. $J$ Toxicol Environ Health 1984, 13:441-469.

141. Pinkerton KE, Joad JP: Influence of air pollution on respiratory health during perinatal development. Clin Exp Pharmacol Physiol 2006, 33:269-272.

142. Wenzel S, Holgate ST: The mouse trap: It still yields few answers in asthma. Am J Respir Crit Care Med 2006, 174:1173-1176.

143. Elliot J, Vullermin P, Robinson P: Maternal cigarette smoking is associated with increased inner airway wall thickness in children who die from sudden infant death syndrome. Am J Respir Crit Care Med 1998, 158:802-806

144. Montuschi P, Collins JV, Ciabattoni G, Lazzeri N, Corradi M, Kharitonov SA, Barnes PJ: Exhaled 8-isoprostane as an in vivo biomarker of lung oxidative stress in patients with COPD and healthy smokers. Am J Respir Crit Care Med 2000, 162:1175-1177. 
145. Petecchia L, Sabatini F, Varesio L, Camoirano A, Usai C, Pezzolo A, Rossi GA: Bronchial airway epithelial cell damage following exposure to cigarette smoke includes disassembly of tight junction components mediated by the extracellular signal-regulated kinase 1/2 pathway. Chest 2009, 135:1502-1512.

146. Sato A, Hoshino Y, Hara T, Muro S, Nakamura H, Mishima M, Yodoi J: Thioredoxin-1 ameliorates cigarette smoke-induced lung inflammation and emphysema in mice. J Pharmacol Exp Ther 2008, 325:380-388.

147. Li N, Wang M, Oberley TD, Sempf JM, Nel AE: Comparison of the prooxidative and proinflammatory effects of organic diesel exhaust particle chemicals in bronchial epithelial cells and macrophages. J Immunol 2002, 169:4531-4541.

148. Boland S, Baeza-Squiban A, Fournier T, Houcine O, Gendron MC, Chevrier M, Jouvenot G, Coste A, Aubier M, Marano F: Diesel exhaust particles are taken up by human airway epithelial cells in vitro and alter cytokine production. Am J Physiol 1999, 276:L604-L613.

149. Lim HB, Ichinose T, Miyabara $Y$, Takano H, Kumagai $Y$, Shimojyo $N$, Devalia $J$, Sagai M: Involvement of superoxide and nitric oxide on airway inflammation and hyperresponsiveness induced by diesel exhaust particles in mice. Free Radic Biol Med 1998, 25:635-644.

150. Li YJ, Kawada T, Matsumoto A, Azuma A, Kudoh S, Takizawa H, Sugawara I: Airway inflammatory responses to oxidative stress induced by low-dose diesel exhaust particle exposure differ between mouse strains. Exp Lung Res 2007, 33:227-244.

151. Ichinose T, Furuyama A, Sagai M: Biological effects of diesel exhaust particles (DEP). II. Acute toxicity of DEP introduced into lung by intratracheal instillation. Toxicology 1995, 99:153-167.

152. Chung KF: Cytokines in chronic obstructive pulmonary disease. Eur Respir J Suppl 2001, 34:50s-59s.

153. D'hulst Al, Maes T, Bracke KR, Demedts IK, Tournoy KG, Joos GF, Brusselle GG: Cigarette smoke-induced pulmonary emphysema in scidmice. Is the acquired immune system required?. Respir Res 2005, 6:147.

154. Bracke KR, D'hulst Al, Maes T, Moerloose KB, Demedts IK, Lebecque S, Joos GF, Brusselle GG: Cigarette smoke-induced pulmonary inflammation and emphysema are attenuated in CCR6-deficient mice. J Immunol 2006, 177:4350-4359.

155. D'hulst Al, Bracke KR, Maes T, De Bleecker JL, Pauwels RA, Joos GF, Brusselle GG: Role of tumour necrosis factor-alpha receptor p75 in cigarette smoke-induced pulmonary inflammation and emphysema. Eur Respir J 2006, 28:102-112

156. Salvi SS, Nordenhall C, Blomberg A, Rudell B, Pourazar J, Kelly FJ, Wilson S, Sandstrom T, Holgate ST, Frew AJ: Acute exposure to diesel exhaust increases IL- 8 and GRO-alpha production in healthy human airways. Am $J$ Respir Crit Care Med 2000, 161:550-557.

157. Nordenhall C, Pourazar J, Blomberg A, Levin JO, Sandstrom T, Adelroth E: Airway inflammation following exposure to diesel exhaust: a study of time kinetics using induced sputum. Eur Respir J 2000, 15:1046-1051.

158. Gowdy K, Krantz QT, Daniels M, Linak WP, Jaspers I, Gilmour MI: Modulation of pulmonary inflammatory responses and antimicrobial defenses in mice exposed to diesel exhaust. Toxicol Appl Pharmacol 2008, 229:310-319.

159. Hiramatsu K, Azuma A, Kudoh S, Desaki M, Takizawa H, Sugawara I: Inhalation of diesel exhaust for three months affects major cytokine expression and induces bronchus-associated lymphoid tissue formation in murine lungs. Exp Lung Res 2003, 29:607-622.

160. Saber AT, Jacobsen NR, Bornholdt J, Kjaer SL, Dybdahl M, Risom L, Loft S, Vogel U, Wallin H: Cytokine expression in mice exposed to diesel exhaust particles by inhalation. Role of tumor necrosis factor. Part Fibre Toxicol 2006, 3:4.

161. Fujimaki H, Kurokawa $Y$, Yamamoto S, Satoh M: Distinct requirements for interleukin- 6 in airway inflammation induced by diesel exhaust in mice. Immunopharmacol Immunotoxicol 2006, 28:703-714.

162. Churg A, Zhou S, Wang X, Wang R, Wright JL: The role of interleukin1 beta in murine cigarette smoke-induced emphysema and small airway remodeling. Am J Respir Cell Mol Biol 2009, 40:482-490.

163. Doz E, Noulin N, Boichot E, Guenon I, Fick L, Le BM, Lagente V, Ryffel B, Schnyder B, Quesniaux VF, Couillin I: Cigarette smoke-induced pulmonary inflammation is TLR4/MyD88 and IL-1R1/MyD88 signaling dependent. J Immunol 2008, 180:1169-1178.

164. Diaz-Sanchez D, Tsien A, Casillas A, Dotson AR, Saxon A: Enhanced nasal cytokine production in human beings after in vivo challenge with diesel exhaust particles. J Allergy Clin Immunol 1996, 98:114-123.
165. Kongerud J, Madden MC, Hazucha M, Peden D: Nasal responses in asthmatic and nonasthmatic subjects following exposure to diesel exhaust particles. Inhal Toxicol 2006, 18:589-594.

166. Behndig AF, Mudway IS, Brown JL, Stenfors N, Helleday R, Duggan ST, Wilson SJ, Boman C, Cassee FR, Frew AJ, Kelly FJ, Sandstrom T, Blomberg A: Airway antioxidant and inflammatory responses to diesel exhaust exposure in healthy humans. Eur Respir J 2006, 27:359-365.

167. Ohtoshi T, Takizawa H, Okazaki H, Kawasaki S, Takeuchi N, Ohta K, Ito K: Diesel exhaust particles stimulate human airway epithelial cells to produce cytokines relevant to airway inflammation in vitro. J Allergy Clin Immunol 1998, 101:778-785.

168. Devalia JL, Bayram H, Abdelaziz MM, Sapsford RJ, Davies RJ: Differences between cytokine release from bronchial epithelial cells of asthmatic patients and non-asthmatic subjects: effect of exposure to diesel exhaust particles. Int Arch Allergy Immunol 1999, 118:437-439.

169. Bayram H, Devalia JL, Khair OA, Abdelaziz MM, Sapsford RJ, Sagai M, Davies RJ: Comparison of ciliary activity and inflammatory mediator release from bronchial epithelial cells of nonatopic nonasthmatic subjects and atopic asthmatic patients and the effect of diesel exhaust particles in vitro. J Allergy Clin Immunol 1998, 102:771-782.

170. Hirota R, Akimaru K, Nakamura $\mathrm{H}$ : In vitro toxicity evaluation of diesel exhaust particles on human eosinophilic cell. Toxicol In Vitro 2008 22:988-994.

171. Vlahos R, Bozinovski S, Hamilton JA, Anderson GP: Therapeutic potential of treating chronic obstructive pulmonary disease (COPD) by neutralising granulocyte macrophage-colony stimulating factor (GM-CSF). Pharmacol Ther 2006, 112:106-115.

172. Ohta K, Yamashita N, Tajima M, Miyasaka T, Nakano J, Nakajima M, Ishii A, Horiuchi T, Mano K, Miyamoto T: Diesel exhaust particulate induces airway hyperresponsiveness in a murine model: essential role of GMCSF. J Allergy Clin Immunol 1999, 104:1024-1030.

173. Krisiukeniene A, Babusyte A, Stravinskaite K, Lotvall J, Sakalauskas R, Sitkauskiene B: Smoking affects eotaxin levels in asthma patients. J Asthma 2009, 46:470-476.

174. Takizawa H, Abe S, Okazaki H, Kohyama T, Sugawara I, Saito Y, Ohtoshi T, Kawasaki S, Desaki M, Nakahara K, Yamamoto K, Matsushima K, Tanaka M, Sagai M, Kudoh S: Diesel exhaust particles upregulate eotaxin gene expression in human bronchial epithelial cells via nuclear factor-kappa B-dependent pathway. Am J Physiol Lung Cell Mol Physiol 2003, 284: L1055-L1062.

175. Diaz-Sanchez D, Jyrala M, Ng D, Nel A, Saxon A: In vivo nasal challenge with diesel exhaust particles enhances expression of the $C C$ chemokines rantes, MIP-1alpha, and MCP-3 in humans. Clin Immunol 2000, 97:140-145.

176. Ying S, O'Connor B, Ratoff J, Meng Q, Fang C, Cousins D, Zhang G, Gu S, Gao Z, Shamji B, Edwards MJ, Lee TH, Corrigan CJ: Expression and cellular provenance of thymic stromal lymphopoietin and chemokines in patients with severe asthma and chronic obstructive pulmonary disease. J Immunol 2008, 181:2790-2798.

177. Bratke K, Klug M, Bier A, Julius P, Kuepper M, Virchow JC, Lommatzsch M: Function-associated surface molecules on airway dendritic cells in cigarette smokers. Am J Respir Cell Mol Biol 2008, 38:655-660.

178. Lommatzsch M, Bratke K, Knappe T, Bier A, Dreschler K, Kuepper M, Stoll P, Julius $P$, Virchow JC: Acute effects of tobacco smoke on human airway dendritic cells in vivo. Eur Respir J 2009, Sep 9, [Epub ahead of print].

179. Demedts IK, Bracke KR, Van Pottelberge G, Testelmans D, Verleden GM, Vermassen FE, Joos GF, Brusselle GG: Accumulation of dendritic cells and increased CCL20 levels in the airways of patients with chronic obstructive pulmonary disease. Am J Respir Crit Care Med 2007, 175:998-1005

180. D'hulst Al, Vermaelen KY, Brusselle GG, Joos GF, Pauwels RA: Time course of cigarette smoke-induced pulmonary inflammation in mice. Eur Respir $J$ 2005, 26:204-213.

181. Robbins CS, Franco F, Mouded M, Cernadas M, Shapiro SD: Cigarette smoke exposure impairs dendritic cell maturation and $\mathrm{T}$ cell proliferation in thoracic lymph nodes of mice. J Immunol 2008, 180:6623-6628.

182. Freeman CM, Martinez FJ, Han MK, Ames TM, Chensue SW, Todt JC, Arenberg DA, Meldrum CA, Getty C, McCloskey L, Curtis JL: Lung Dendritic Cell Expression of Maturation Molecules Increases with Worsening COPD. Am J Respir Crit Care Med 2009, 180(12):1179-1188. 
183. Thomson NC, Chaudhuri R, Livingston E: Asthma and cigarette smoking. Eur Respir J 2004, 24:822-833.

184. Gorska K, Maskey-Warzechowska M, Krenke R: Airway inflammation in chronic obstructive pulmonary disease. Curr Opin Pulm Med 2009, Nov 9, [Epub ahead of print].

185. Terada N, Maesako K, Hiruma K, Hamano N, Houki G, Konno A, Ikeda T, Sai M: Diesel exhaust particulates enhance eosinophil adhesion to nasal epithelial cells and cause degranulation. Int Arch Allergy Immunol 1997, 114:167-174.

186. Nightingale JA, Maggs R, Cullinan P, Donnelly LE, Rogers DF, Kinnersley R, Chung KF, Barnes PJ, Ashmore M, Newman-Taylor A: Airway inflammation after controlled exposure to diesel exhaust particulates. Am J Respir Crit Care Med 2000, 162:161-166.

187. Stanescu D, Sanna A, Veriter C, Kostianev S, Calcagni PG, Fabbri LM, Maestrelli P: Airways obstruction, chronic expectoration, and rapid decline of FEV1 in smokers are associated with increased levels of sputum neutrophils. Thorax 1996, 51:267-271.

188. Salvi S, Blomberg A, Rudell B, Kelly F, Sandstrom T, Holgate ST, Frew A: Acute inflammatory responses in the airways and peripheral blood after short-term exposure to diesel exhaust in healthy human volunteers. Am J Respir Crit Care Med 1999, 159:702-709.

189. Diaz-Sanchez D, Dotson AR, Takenaka H, Saxon A: Diesel exhaust particles induce local $\lg E$ production in vivo and alter the pattern of $\lg E$ messenger RNA isoforms. J Clin Invest 1994, 94:1417-1425.

190. Warr GA, Martin RR, Sharp PM, Rossen RD: Normal human bronchial immunoglobulins and proteins: effects of cigarette smoking. Am Rev Respir Dis 1977, 116:25-30.

191. Tsoumakidou M, Elston W, Zhu J, Wang Z, Gamble E, Siafakas NM, Barnes NC, Jeffery PK: Cigarette smoking alters bronchial mucosal immunity in asthma. Am J Respir Crit Care Med 2007, 175:919-925.

192. Di Benedetto G: Passive smoking in childhood. J R Soc Health 1995, 115:13-16

193. Mamessier E, Nieves A, Vervloet D, Magnan A: Diesel exhaust particles enhance T-cell activation in severe asthmatics. Allergy 2006, 61:581-588.

194. Broekema M, ten Hacken NH, Volbeda F, Lodewijk ME, Hylkema MN, Postma DS, Timens W: Airway Epithelial Changes in Smoking but not in Ex-Smoking Asthmatics. Am J Respir Crit Care Med 2009, 180(12):1170-1178.

195. Takizawa R, Pawankar R, Yamagishi S, Takenaka H, Yagi T: Increased expression of HLA-DR and CD86 in nasal epithelial cells in allergic rhinitics: antigen presentation to $T$ cells and up-regulation by diesel exhaust particles. Clin Exp Allergy 2007, 37:420-433.

196. Diaz-Sanchez D, Penichet-Garcia M, Saxon A: Diesel exhaust particles directly induce activated mast cells to degranulate and increase histamine levels and symptom severity. J Allergy Clin Immunol 2000, 106:1140-1146.

doi:10.1186/1465-9921-11-7

Cite this article as: Maes et al: Mouse models to unravel the role of inhaled pollutants on allergic sensitization and airway inflammation. Respiratory Research 2010 11:7.

\section{Submit your next manuscript to BioMed Central and take full advantage of:}

- Convenient online submission

- Thorough peer review

- No space constraints or color figure charges

- Immediate publication on acceptance

- Inclusion in PubMed, CAS, Scopus and Google Scholar

- Research which is freely available for redistribution

Submit your manuscript at www.biomedcentral.com/submit
Biomed Central 